Nat. Hazards Earth Syst. Sci., 18, 983-995, 2018

https://doi.org/10.5194/nhess-18-983-2018

(C) Author(s) 2018. This work is distributed under the Creative Commons Attribution 4.0 License.

\title{
Large drainages from short-lived glacial lakes in the Teskey Range, Tien Shan Mountains, Central Asia
}

\author{
Chiyuki Narama $^{1}$, Mirlan Daiyrov ${ }^{1,2}$, Murataly Duishonakunov ${ }^{3}$, Takeo Tadono ${ }^{4}$, Hayato Sato ${ }^{1,5}$, Andreas Kääb ${ }^{6}$, \\ Jinro Ukita $^{1}$, and Kanatbek Abdrakhmatov ${ }^{7}$ \\ ${ }^{1}$ Department of Environmental Science, Niigata University, Niigata, Japan \\ ${ }^{2}$ Central-Asian Institute for Applied Geosciences (CAIAG), Bishkek, Kyrgyzstan \\ ${ }^{3}$ Department of Physical Geography, Kyrgyz National University, Bishkek, Kyrgyzstan \\ ${ }^{4}$ Japan Aerospace Exploration Agency (JAXA), Tsukuba, Japan \\ ${ }^{5}$ Kokusai Kogyo Co., Ltd, Tokyo, Japan \\ ${ }^{6}$ Department of Geosciences, University of Oslo, Norway \\ ${ }^{7}$ Institute of Seismology, Kyrgyz Academy of Science, Bishkek, Kyrgyzstan
}

Correspondence: Chiyuki Narama (narama@env.sc.niigata-u.ac.jp)

Received: 21 June 2017 - Discussion started: 11 July 2017

Revised: 5 January 2018 - Accepted: 22 January 2018 - Published: 3 April 2018

\begin{abstract}
Four large drainages from glacial lakes occurred during 2006-2014 in the western Teskey Range, Kyrgyzstan. These floods caused extensive damage, killing people and livestock as well as destroying property and crops. Using satellite data analysis and field surveys of this area, we find that the water volume that drained at Kashkasuu glacial lake in 2006 was $194000 \mathrm{~m}^{3}$, at western Zyndan lake in 2008 was $437000 \mathrm{~m}^{3}$, at Jeruy lake in 2013 was $182000 \mathrm{~m}^{3}$, and at Karateke lake in 2014 was $123000 \mathrm{~m}^{3}$. Due to their subsurface outlet, we refer to these short-lived glacial lakes as the "tunnel-type", a type that drastically grows and drains over a few months. From spring to early summer, these lakes either appear, or in some cases, significantly expand from an existing lake (but non-stationary), and then drain during summer. Our field surveys show that the short-lived lakes form when an ice tunnel through a debris landform gets blocked. The blocking is caused either by the freezing of stored water inside the tunnel during winter or by the collapse of ice and debris around the ice tunnel. The draining then occurs through an opened ice tunnel during summer. The growth-drain cycle can repeat when the ice-tunnel closure behaves like that of typical supraglacial lakes on debris-covered glaciers. We argue here that the geomorphological characteristics under which such short-lived glacial lakes appear are (i) a debris landform containing ice (ice-cored moraine complex), (ii) a depression with water supply on a debris landform as a po-
\end{abstract}

tential lake basin, and (iii) no visible surface outflow channel from the depression, indicating the existence of an ice tunnel. Applying these characteristics, we examine 60 depressions $\left(>0.01 \mathrm{~km}^{2}\right)$ in the study region and identify here 53 of them that may become short-lived glacial lakes, with 34 of these having a potential drainage exceeding $10 \mathrm{~m}^{3} \mathrm{~s}^{-1}$ at peak discharge.

\section{Introduction}

The northern Tien Shan in Kyrgyzstan, Central Asia, contains many small glacial lakes at glacier fronts. Compared to many large proglacial lakes in the eastern Himalayas that exceed $0.1 \mathrm{~km}^{2}$ (Komori et al., 2004; Nagai et al., 2017), $74 \%$ of the lakes in the study region had area extents of less than $0.01 \mathrm{~km}^{2}$ in 2014 (Narama et al., 2015). Nevertheless, in recent decades rapid drainage from such lakes in central Asian mountain ranges has caused severe damage, impacting residents in nearby mountain villages (Kubrushko and Staviskiy, 1978; Kubrushko and Shatravin, 1982; Baimoldaev and Vinohodov, 2007; Narama et al., 2009). More recently, catastrophic damage occurred in 1998 from a drainage of the Archa-Bashy glacial lake in the Alay Range of the GissarAlay region. This small lake, which had formed on a debris landform at the glacier front, suddenly released water. Al- 
though the volume of released water was relatively small, the flood killed more than 100 residents along the river in Shahimardan village in Uzbekistan (UNEP, 2007), demonstrating that flood volume alone is an insufficient indicator of damage potential.

In a similar event on 7 August 2002 in the Shahdara Valley, Pamir, Tajikistan, a $320000 \mathrm{~m}^{3}$ drainage from a small lake caused a mudflow that buried the Dasht village on the alluvial fan and killed 25 people (Mergili et al., 2012). In the northern Tien Shan, a drainage occurred from the western Zyndan glacial lake in the Teskey Range on 24 July 2008 (Narama et al., 2010a). The latter event discharged $437000 \mathrm{~m}^{3}$ of water, causing extensive damage, killing three people and many livestock, as well as destroying a bridge, a road, two houses, crops, and an important fish hatchery. These lakes are a type of short-lived glacial lake (non-stationary, but existing only over a short period) that appear and discharge within a few months or one year (Narama et al., 2010a; Mergili et al., 2013).

Unlike the supraglacial cases (e.g., in the Italian Alps; Haeberli, et al., 2002; Harrison et al., 2015), the Central Asian cases are a different type of short-lived glacial lake that appear at the glacier front on debris landforms with buried ice. Monitoring of such lakes is complicated due to their sudden and short appearance (Narama et al., 2010a). Additionally, their drainage through ice tunnels differs from that from many other glacial-lake outburst floods (GLOFs) in the eastern Himalayas (Bhutan and eastern Nepal), which discharge through the failure of a moraine dam (Yamada and Sharma, 1993; Watanabe and Rothacher, 1996; Komori et al., 2012). In addition, the growth period of a short-lived lake also differs from the large proglacial lakes that have continued to expand since the 1950s-1960s in the eastern Himalayas (Ageta et al., 2000).

In the western Teskey Range of the Tien Shan mountains, several large floods occurred from a glacial lake at the Angisay Glacier in 1974, 1975, and 1980 (Kubrushko and Staviskiy, 1978; Kubrushko and Shatravin, 1982). Since then, large drainages have occurred at the Kashkasuu glacial lake in 2006, the western Zyndan lake in 2008, the Jeruy lake in 2013, and the Karateke lake in 2014. Of these, the drainage from the western Zyndan lake was examined in Narama et al. (2010a). To understand the geomorphological characteristics of this type of short-lived glacial lake, we examine all four of these recent floods as well as depressions with shortlived lakes using field surveys and satellite data. To help decrease the damage from such glacier related disasters, we assess the locations and volumes of these depressions and current glacial lakes. In addition, we discuss the geomorphological characteristics that lead to short-lived glacial lakes.

\section{Study area}

Along the southern shoreline of Lake Issyk-Kul in Kyrgyzstan, Central Asia, lies the Teskey Range, Tien Shan (Fig. 1). The Tien Shan is a reactivated area of Paleozoic deformation. Although this region had a low-relief surface following the Paleozoic orogenies, Late Cenozoic deformation has resulted in this surface being warped across a series of mountain ranges cored by crystalline basement and previously deformed Paleozoic sedimentary and metamorphic rocks (Abdrakhmatov et al., 2001; Burgette et al., 2017). Here, surrounding Lake Issyk-Kul, lies the Issyk-Kul basin, bound to the south by the actively growing Teskey Range. The Teskey Range has a ridgeline at $4800-3700 \mathrm{~m}$ a.s.l. above small alpine glaciers.

Most precipitation in the Teskey Range occurs from May to July, when the weakened Siberian High allows moisture to arrive from the west (Aizen et al., 1995). In general, the northern Tien Shan blocks moisture carried by the westerlies, causing larger annual precipitation amounts in the Pskem, Talas, Kyrgyz, Ili, and Kungöy Ranges, as compared to the Teskey Range (Narama et al., 2010b). In this range, the average annual precipitation ranges from $363 \mathrm{~mm}$ (19811999) in the western part (Karakujur station; $3000 \mathrm{~m}$ a.s.l.), to $247 \mathrm{~mm}$ (1981-1999) in the central part (Tien Shan station; $3600 \mathrm{~m}$ a.s.l.), and to $597 \mathrm{~mm}$ (1981-1987) in the eastern part (Chong-Kyzylsuu; $2550 \mathrm{~m}$ a.s.1.).

Glacier shrinkage in the outer and inner ranges also varies significantly throughout the Tien Shan (Narama et al., 2010b). The glacier area in the Teskey Range has decreased less in the west than in the east (Narama et al., 2006; Katuzov and Shahgedanova, 2009).

The population and villages are distributed over the northern part of the Teskey Range. There, villagers use the large alluvial fans at the mountain piedmont as pasturage or agricultural fields.

\section{Methods}

\subsection{Field surveys}

In the study area of the western Teskey Range, we investigated glacial lakes and three recent (2006, 2013, and 2014) large drainages based on field surveys (2007-2016) and satellite data analysis. The drainages include those from the Kashkasuu, Jeruy, and Karateke glacial lakes shown in Fig. 1. We visited 25 glacial lakes, including lakes that caused large drainages, and investigated landforms (distance and location of ice tunnel, depression of lake basin) and lake levels after drainage using a Trimble GeoExplorer 6000 (cm-precision edition) and a Leica GPS 900. We obtained positional accuracy ranges between 20 and $70 \mathrm{~cm}$, through differential postprocessing of Trimble GPS data, using the Kyrgyz GPS reference station. To estimate the water volume of current lakes, 


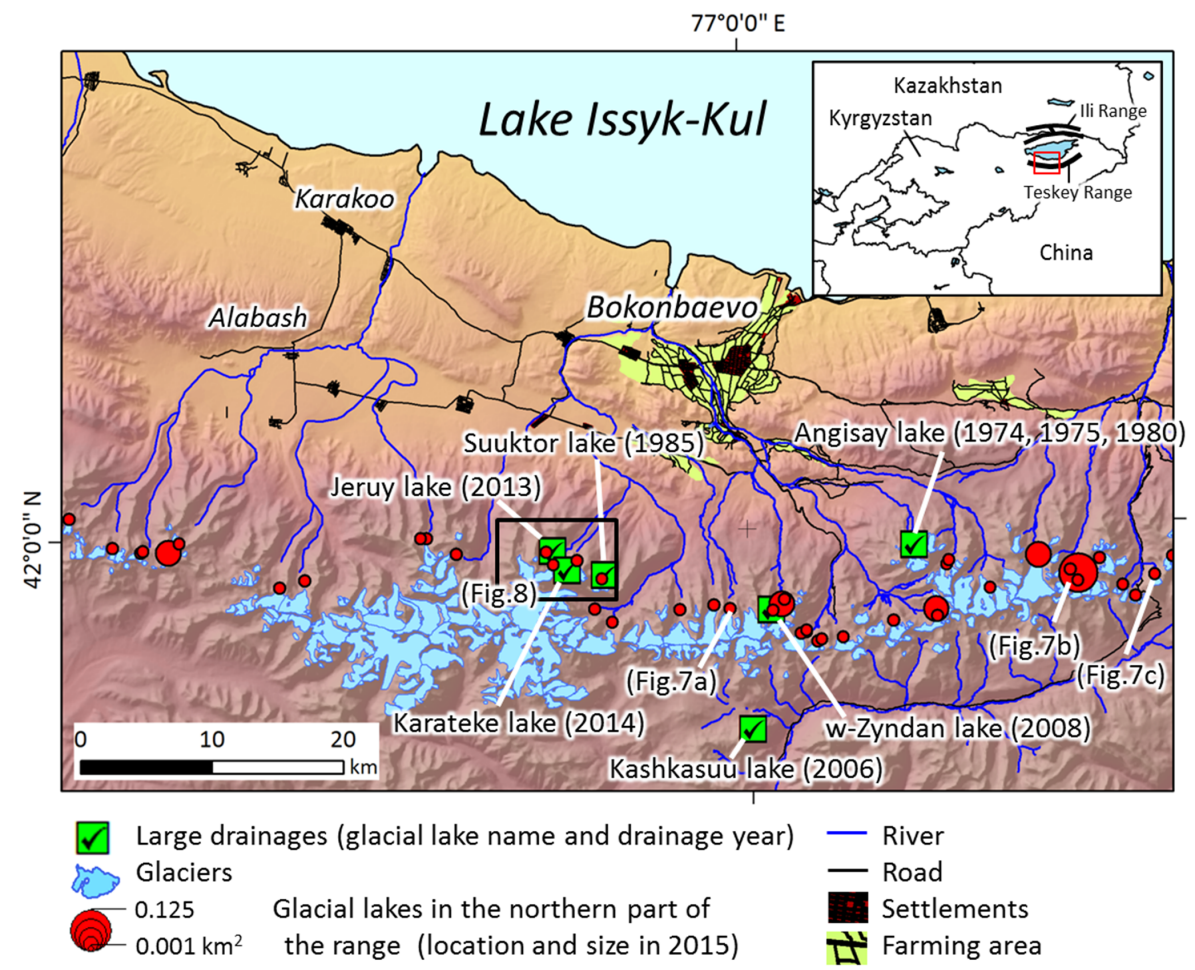

Figure 1. The study area in the western part of the Teskey Range, Kyrgyzstan. Green boxes show the location of large drainage events with their name and flooding years labelled. Location and size of red circles show locations and size of lakes in 2015.

we measured water depths in 10 current lakes in the area using an inflatable boat (PVL-260) and a fish finder with GPS (LOWRANCE HDS-5; Fig. 1). In the downstream zones of Jeruy and Karateke lakes, we investigated clast diameter, sedimentary facies, extent of flood deposit, and their eroded channels. In addition, we interviewed residents of Jeruy village about local floods.

\subsection{Satellite data analysis}

We investigated the evolution of the Kashkasuu, Jeruy, and Karateke lakes using the Advanced Land Observing Satellite (ALOS) with the Panchromatic Remote-sensing Instrument for Stereo Mapping (PRISM; $2.5 \mathrm{~m}$ resolution), as well as the ALOS Advanced Visible and Near Infrared Radiometer-2 (AVNIR-2; 10m resolution), Landsat7 ETM+, and Landsat 8 OLI data. The ALOS and Landsat images were fused, and pan-sharpened images using the PCI Geomatica software were used to estimate glacial lake areas through manual mapping of the glacial lake boundaries. We also estimated the water volumes after drainage at Kashkasuu lake using an ALOS PRISM digital surface model (DSM) taken on 11 November 2010, as well as the water volumes after drainage at Jeruy and Karateke lakes from DSMs made from images taken on 8-10 August 2016 by an unmanned aerial vehicle (UAV; Phantom 4). These images were converted to an orthoimage and DSM using the software Pix4D map- per with GCPs on Google Earth and ALOS PRISM DSM (19 November 2007). Compared to the GPS-measured elevation on the debris landform at Jeruy Glacier in 2014 (9 August), the UAV DSM elevation is lower by $7.8 \pm 1.0 \mathrm{~m}$. The PRISM DSMs were processed by JAXA EORC as a highlevel product. The standard deviations of the PRISM DSM height errors (PRISM DSM without ground control points, GCPs, minus reference DSM) are between 4.9 and $8.7 \mathrm{~m}$ (Takaku and Tadono, 2009; Tadono et al., 2012).

In general, a short-lived glacial lake appears in a depression (shallow hollow) on the debris landform at glacier fronts. To estimate the location and maximum volume of a potential lake basin, we used a water-filling model to extract depressions on the debris landforms at glacier fronts. The model used PRISM DSM data taken on 17 September 2007, 19 November 2007, 21 October 2009, $10 \mathrm{Au}-$ gust 2010, 10 November 2010, and 27 November 2010. We set $0.01 \mathrm{~km}^{2}$ as the minimum depression size because recent drainages with damages are caused from short-lived lakes exceeding $0.01 \mathrm{~km}^{2}$. To test the accuracy of the waterfilling model, we compare its result to an estimate based on GPS data from the western Zyndan lake before its drainage (24 July 2008). As shown in Fig. 2, the GPS data along the shoreline (ice line) of the western Zyndan lake before drainage coincides well with the extracted outline of the depression from the model. Existing lakes are also extracted 


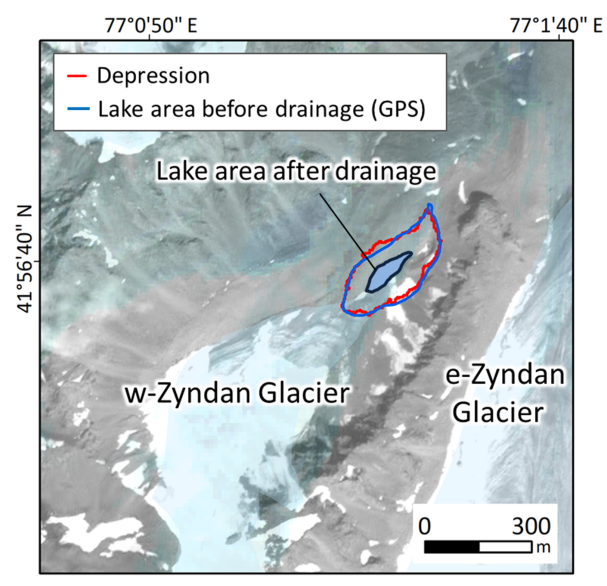

Figure 2. Western Zyndan glacial lake at which a large drainage event occurred on 24 July 2008 (location in Fig. 1). The blue line shows the lake perimeter before drainage, according to GPS measurements on 29 July 2008. The red line shows the depression, according to ALOS PRISM DSM data.

using ALOS AVNIR-2 images taken on 17 September 2007, 3, 8 September 2008, 10 August 2010.

For the assessment of floods, it is of significant advantage to anticipate the flow type and map the landform of a valley mouth reached by the flood, as the latter determines the range and form of the debris spread. To distinguish flood types (i.e., debris flow vs. water flood), we estimated the erodible channel distance as the distance over which the channel has an angle exceeding $10^{\circ}$ using NASA's shuttle radar topography mission digital elevation model (SRTM) DEM (30 m resolution). (This data covers regions outside the ALOS DSM region that we plan to use for further study.) In addition, we used satellite data to classify the lowland landforms in 23 valleys in the northern part of the western Teskey Range into valley landform and alluvial fan.

\section{Results}

\subsection{Evolution of three short-lived glacial lakes}

In the following, we consider the area changes of the Kashkasuu lake in 2006, Jeruy lake in 2013, and Karateke lake in 2014. (The western Zyndan lake is described in detail in Narama et al., 2010a). Figure 3 shows their changes observed from satellite images, Fig. 1 shows their locations. Kashkasuu lake is in the southern part of the Teskey Range and directly contacts a glacier, so we refer to it as a "glaciercontact" type. In Fig. 3a, we show that its area increases on 21 June 2005 (compared to 6 September 2004, not shown), and remains nearly the same on 23 May 2006. It grows until 26 July 2006, expanding to $0.025 \mathrm{~km}^{2}$, but the lake shrinks again to $0.004 \mathrm{~km}^{2}$ on 11 August 2006. Thus, lake water has discharged between 26 July and 11 August 2006. Based on the lake area on 26 July 2006 and the PRISM DSM, we estimate that $194000 \mathrm{~m}^{3}$ of water volume discharged in total.

To the northwest of Kashkasuu lies Jeruy glacial lake. Images in Fig. $3 \mathrm{~b}$ show this lake to be unrecognizable on 18 May 2013, but clearly visible by 19 June 2013. By 6 August 2013, it has grown to $0.035 \mathrm{~km}^{2}$ with an estimated volume of $182000 \mathrm{~m}^{3}$. The lake, which has glacier contact, drains on 15 August 2013, but some water remains on 23 September.

To the east lies Karateke lake. This lake is without glacier contact and located on a debris landform at the glacier front. Figure $3 \mathrm{c}$ shows the lake area to be only $0.001 \mathrm{~km}^{2}$ on 5 May 2014, but expanding to $0.02 \mathrm{~km}^{2}$ on 30 June 2014 , and then decreasing to $0.016 \mathrm{~km}^{2}$ on 16 July immediately before drainage on 17 July 2014. After drainage, its area becomes $0.001 \mathrm{~km}^{2}$. During this drainage, $123000 \mathrm{~m}^{3}$ of water was discharged.

These three lakes, as well as the western Zyndan lake that discharged $437000 \mathrm{~m}^{3}$ on 24 July 2008 causing a large flood (Narama et al., 2010a), all appear in May and grow rapidly in June and July (Fig. 4), then discharge between mid-July and mid-August. Thus, all four lakes are examples of a "shortlived glacial lake" that suddenly appears and grows over two or three months, with drainage occurring in the summer. Considering the growth of the lakes, the Kashkasuu glacial lake appeared and remained from the previous year, but then grew again. But the Karateke, Jeruy, and western Zyndan lakes evolved and grew from an initially empty basin during the same year.

\subsection{Geomorphological evidence of drainage from the short-lived lakes}

To better understand the behaviour of the lakes, particularly their drainage, we investigated adjacent landforms in a field survey. At the Kashkasuu lake in 2007, a debris landform containing ice was found at the glacier front. The ice rich debris landforms are also called moraine complex (Shatravin, 2007; Janský et al., 2010; Bolch et al., 2014). The debris landform, composed of debris and ice, remained from glacier shrinkage. The Kashkasuu lake expanded on the large depression (hollow) with glacier contact. No surface channels were visible, but we observed a subsurface channel that developed inside of the debris landform. It was a $300 \mathrm{~m}$-long ice tunnel with a water stream from the lake to the tunnel outlet. The lake water was discharged through this ice tunnel between 26 July and 11 August 2006 (Fig. 3a). From August 2006 (before drainage) to September 2007, GPS data shows the lake level dropping by $10 \mathrm{~m}$. This large drainage damaged the mountain road and a bridge along the Uchemchek River.

We observed exposed ice and ice tunnels on similar debris landforms in front of the Jeruy and Karateke Glaciers in 2014 (Fig. 5a, b), and both debris landforms contain buried ice. Jeruy lake appeared in the depression of a basin with glacier 

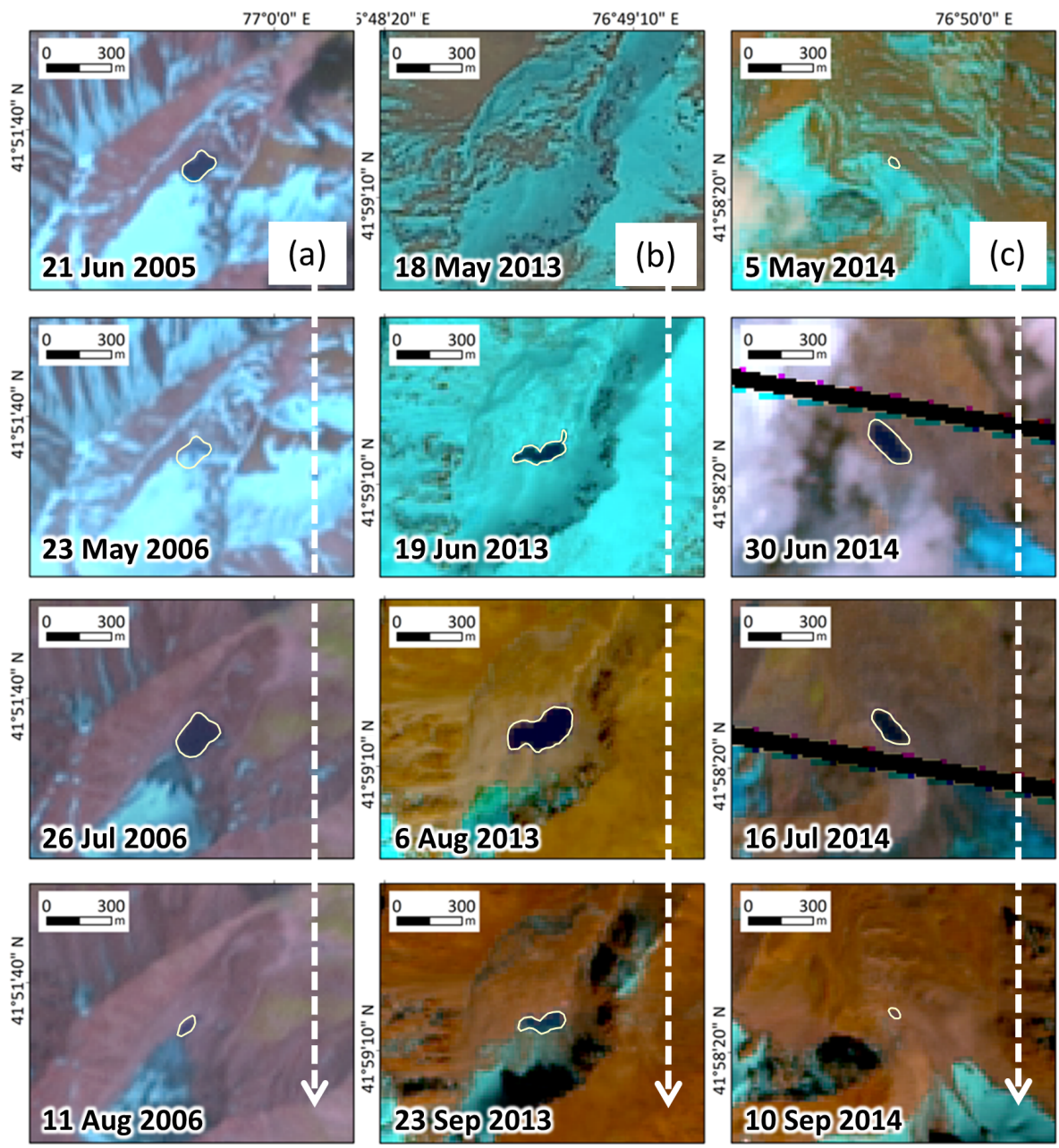

Figure 3. Changes of three lakes. Column (a) is Kashkasuu, (b) is Jeruy, and (c) is Karateke lake. Images are from Landsat7 ETM+ and Landsat8 OLI. The locations are in Fig. 1.

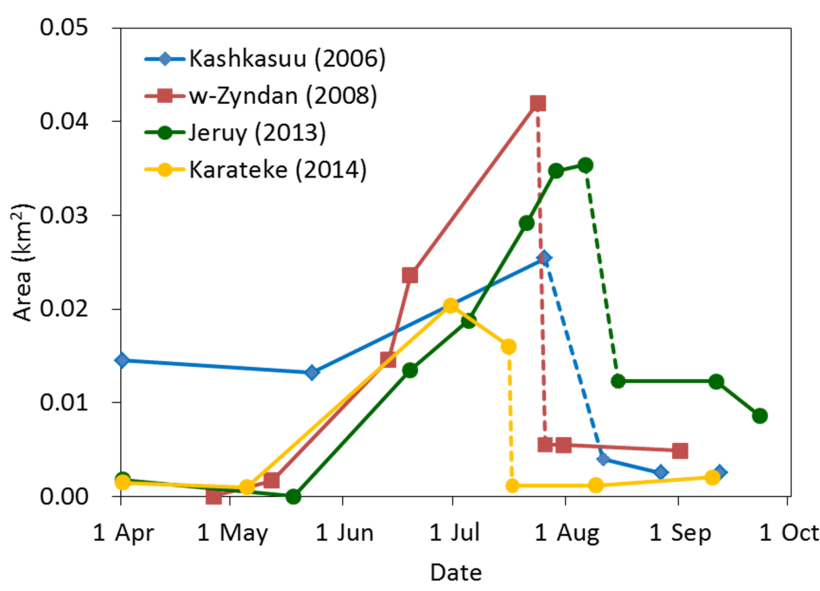

Figure 4. Seasonal area changes of four short-lived glacial lakes. Dashed line segments indicate drainages. contact. The middle point of the ice tunnel is at a $4-5 \mathrm{~m}$ depth (Fig. 5c). Karateke lake also formed in an empty depression, but without glacier contact. For the Karateke lake, meltwater from the glacier terminus flows into the depression, but for the outlets of both lakes we observed no visible surface outflow channel from either depression. However, we found the Jeruy depression to have a $250 \mathrm{~m}$-long ice tunnel and the Karateke to have $500 \mathrm{~m}$ long. For the Karateke lake, the ice tunnel is $4 \mathrm{~m}$ wide at the entry point of the debris landform (Fig. 5d).

Our field survey thus indicates that lake water from the Kashkasuu, Jeruy, and Karateke lakes discharged through ice tunnels inside of debris landforms, as was found previously for the western Zyndan lake (Narama et al., 2010a). In these debris landforms, there are no visible surface outflow channels and most meltwater from the glacier flows through an ice tunnel. Hence, we consider these short-lived glacial lakes as "tunnel-type" to distinguish them from those that 
discharge through different mechanisms (e.g., dam failure, surface channel blockage).

\subsection{Flood deposits and landforms}

Regarding the flood deposits from the lakes studied, the Jeruy and Karateke Valleys are located side by side (Fig. 1), but they produce different debris-flow types and damage. The flood deposits from the Jeruy drainage consist of matrix support deposits of clasts of mostly $0.20-0.30 \mathrm{~m}$ diameter but also including boulders of $1-3 \mathrm{~m}$ diameter (Fig. 6a). From an interview with a local resident of Jeruy village we confirmed that the flow speed from the Jeruy flood was low on the alluvial fan. The flood stream from the Jeruy glacial lake separated into two routes on the large alluvial fan and did not flow along the present water stream. On the alluvial fan, the flood caused a bridge collapse and damaged an irrigation channel, a road, many tombs, an agriculture field, and a property fence. In comparison, flood deposits from Karateke lake consist of clast-supported deposits with large boulders of 1-2 $\mathrm{m}$ diameter (Fig. 6b), and such deposits are limited to the riverbed. Damage from the Karateke flood was limited to two bridges along the river. The flood deposits of the western Zyndan were similar to the Karateke deposits.

For the Jeruy Valley (Fig. 6c), the uneroded flat riverbed section in the upper part is short and the eroded section is long. In contrast, for the Karateke Valley the upper part consists of a flat valley with only a short highly eroded section (Fig. 6d). The differently eroded distances are related to the valley landforms in the upper valley from past glaciation. When a steep slope starts at the end of a flat valley, the flood wave is able to gather debris, transforming into a debris flow. As an indication of a flood wave, grass was flattened by water in the riverbed after drainage from the western Zyndan lake (Narama et al., 2010a).

The degree of entrainment and the resulting changes in water and debris content influence the flow speed (Breien et al., 2008). In the flat valley section below the Karateke lake, we also observed flattened grass along the river. Although the Jeruy drainage has a long eroded section that can indicate a fast flow, here the flood did not include many large boulders. The flow was relatively slow on the alluvial fan. In contrast, dense debris flows can be quite fast. During experiments in the Ili Range of the northern Tien Shan, Kazakhstan, the mean density of highly mobile debris flow reached $2200 \mathrm{~kg} \mathrm{~m}^{-3}$ with water content below $10 \%$ (Baimoldaev and Vinohodov, 2007; Evans and Delaney, 2015). When the eroded material is dry, entrainment produces a high concentration of solids in the slurry with associated increases in the viscosity, cohesion, and friction, all of which could reduce mobility (Breien et al., 2008).

\subsection{Volume size of existing lakes and depressions}

To estimate the water volume and basin form of current glacial lakes, we measured the depths and geolocations of 10 lakes using an inflatable boat and fish finder with GPS. All 10 lakes were less than $30 \mathrm{~m}$ deep. Profiles of three of them are shown in Fig. 7. Lakes in the study area are small; of the 160 glacial lakes over $0.001 \mathrm{~km}^{2}$ in the Teskey Range, $68 \%$ of them are less than $0.01 \mathrm{~km}^{2}$ (Narama et al., 2015). The resulting profiles of the lake basins at glacier fronts are asymmetrical, as shown in Fig. 7b and c, with a greater depth and steeper slope at the glacier terminus side. We found a submerged moraine at the lake bottom of the eastern Zyndan lake. Such a moraine prevents a complete discharge of all lake water, but most observed lakes had no such internal barriers.

The short-lived glacial lake type studied here appears in a depression on a debris landform containing buried ice. To find the locations of such depressions, we used the PRISM DSMs ( $2.5 \mathrm{~m}$ resolution) to measure the distribution and volume of depressions of potential lake basins. In total, we found 60 depressions exceeding $0.01 \mathrm{~km}^{2}$ in the northern part of the western Teskey Range. A short-lived glacial lake can appear at such a depression only if it receives sufficient meltwater. Thus, we distinguished the depressions as those with glacier contact and those without glacier contact (Fig. 8). Of the 60 depressions, 37 (i.e., 62\%) of the depressions had glacier contact in which meltwater can flow in from glacier termini.

The depressions without glacier contact are of the "water accumulation" and "non-accumulation" types. The depressions of water accumulation type can receive meltwater from the glacier because the depression is connected to it via one or more subsurface channels. In contrast, the nonaccumulation type is not connected to a water channel and cannot get substantial amounts of water within short time. We found 23 depressions of the water accumulation type, and each may become a short-lived lake such as the Karateke lake (Fig. 3c). In addition, we determined whether or not the depression had a surface outflow channel. Among the 60 depressions, 7 depressions had a surface outflow channel and thus cannot hold a short-lived lake of the tunnel-type studied here.

The relationship between area and volume of the 10 measured lakes agrees with those found previously. In the plot of Fig. 9, we also show the four large drainages of the Kashkasuu, w-Zyndan, Jeruy, and Karateke glacial lakes, as well as depressions in this study area, and six lakes from previous studies in the Kyrgyz and Ili Ranges (Igor Severskiy, personal communication, 2009; Janský et al., 2010). The regression-line formula between area and volume of existing lakes was calculated using only measurement data (present and previous studies), and was then used to estimate the water volume of current lakes. The larger lakes have volumes above the regression line because such depressions tend to 


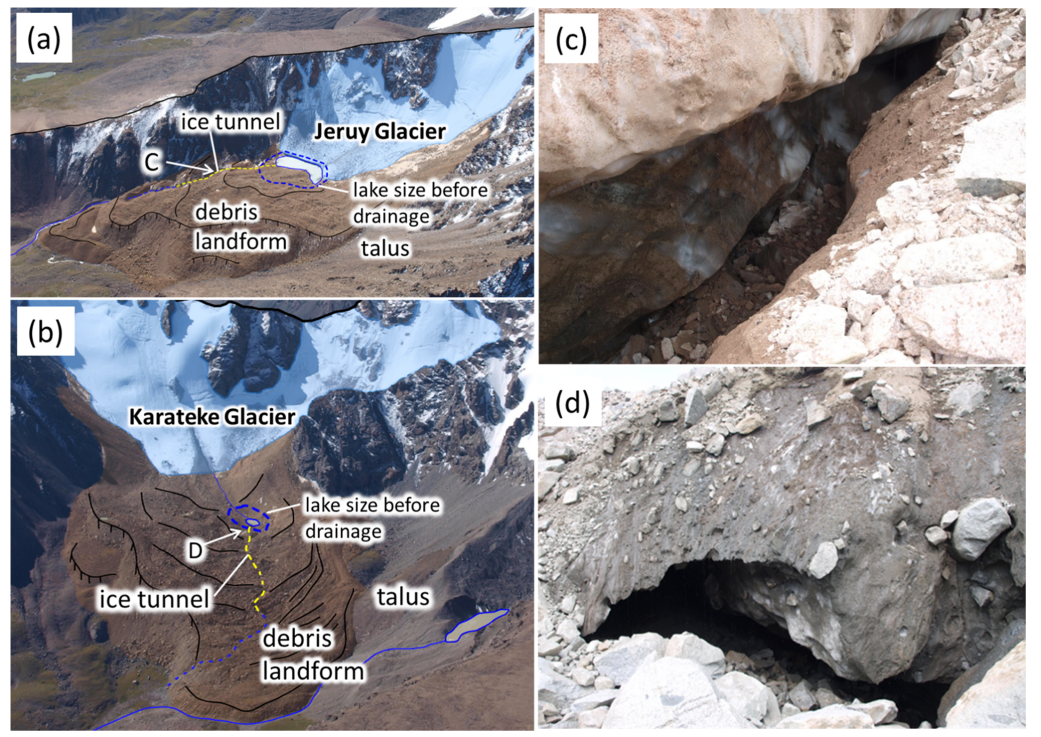

Figure 5. Surface details of the Jeruy and Karateke Glaciers (locations in Fig. 1). In (a) and (b), the blue dashed lines show the lake size before drainage (Photo: 21 August 2014). Yellow dashed lines locate ice-tunnels. (c) The ice tunnel in the middle of the debris landform at the Jeruy Glacier (Photo: 9 August 2014). (d) The entry point of the ice tunnel at the front of the Karateke Glacier (Photo: 8 August 2014). The glacial lake with glacier contact expanded into the Jeruy Glacier, and the glacial lake without glacier contact developed in front of the Karateke Glacier.
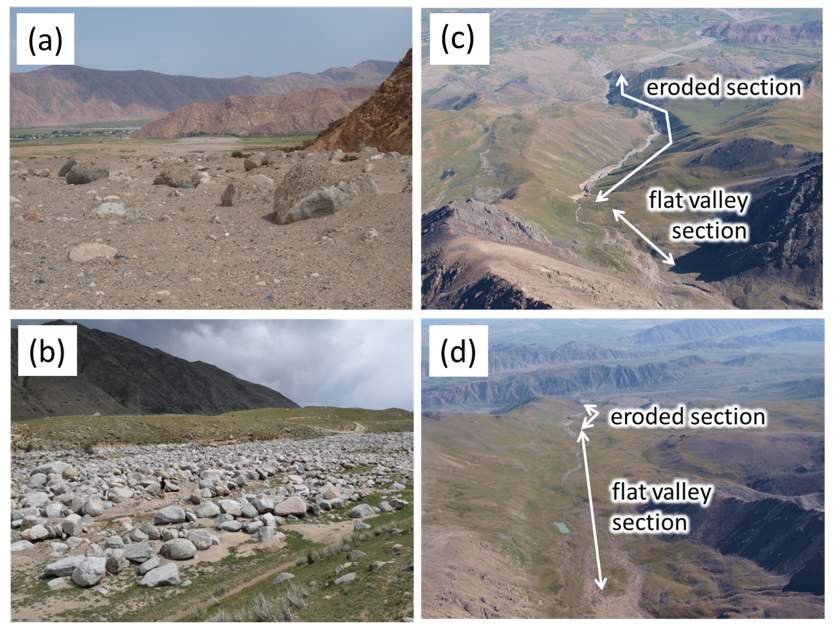

Figure 6. Flood deposits and valley landforms in the Jeruy $(\mathbf{a}, \mathbf{c})$ and Karateke (b, d) Valleys (Photos a: 13 August 2014, b: 15 August 2015, c, d: 21 August 2014).

have steeper sides. Considering those large area lakes, one could make a second-order fit that includes the depressions without a lake. However, we use the simpler first-order fit because our analyses below all use lakes with areas below $0.06 \mathrm{~km}^{2}$. In this range, the two fits would be the same.

\section{Discussion}

\subsection{Geomorphological characteristics of tunnel-type, short-lived glacial lakes}

The field surveys of the four short-lived lakes revealed that, in each case, water discharged through an ice tunnel inside an ice rich debris landform. Our satellite observations of these short-lived glacial lakes show them to appear as a small pond in May and to expand over June and July. The field surveys showed this behaviour to be due to (i) the blockage and closure of ice tunnels, and (ii) rapid melting of snow and ice in the upstream area. The ice tunnels become blocked due to freezing of stored water during winter or deposition of ice and debris by tunnel collapse. Later, their drainage between the end of July and mid-August occurred when their ice tunnel opened, due to subsurface ice melting or evacuation of debris at the closure point.

This drainage process seems similar to the closure and opening (connection) of an englacial conduit for a supraglacial lake on a debris-covered glacier (Benn et al., 2001; Gulley and Benn, 2007; Gulley et al., 2009). Supraglacial lakes have a seasonal variability and can be transient or recurring, depending on the connectivity to englacial network (Miles et al., 2017a, b; Benn et al., 2017; Narama et al., 2017). The formation and sudden drainage of supraglacial ponds have also occurred in the Cordillera Blanca, Peru (Emmer et al. 2015). Several large drainages from supraglacial lakes through englacial conduits have occurred on debris-covered glaciers without a large proglacial 

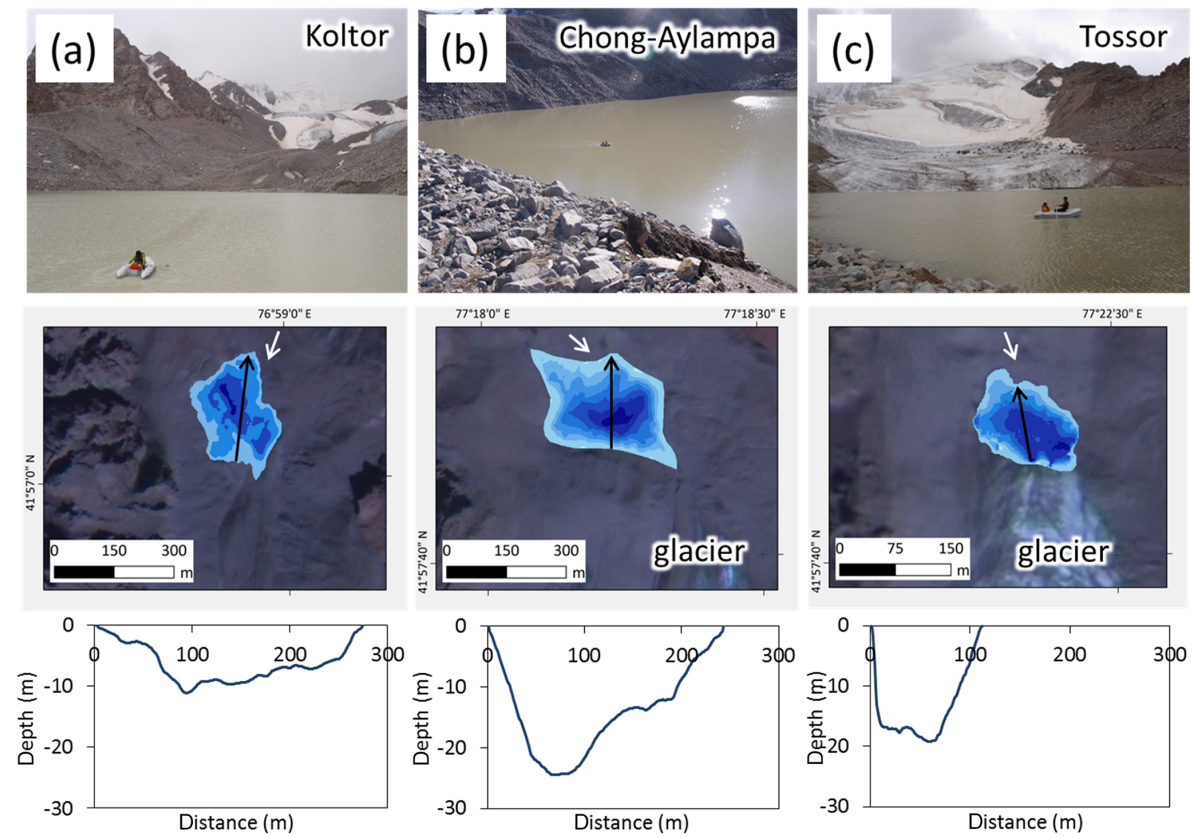

Figure 7. Photos, lake basin maps, and depth profiles of three glacial lakes. (a) Koltor, (b) Chong-Aylampa, (c) Tossor lakes (locations in Fig. 1). Black and white arrows on the lake basin maps show each basin profile line and photo direction, respectively.

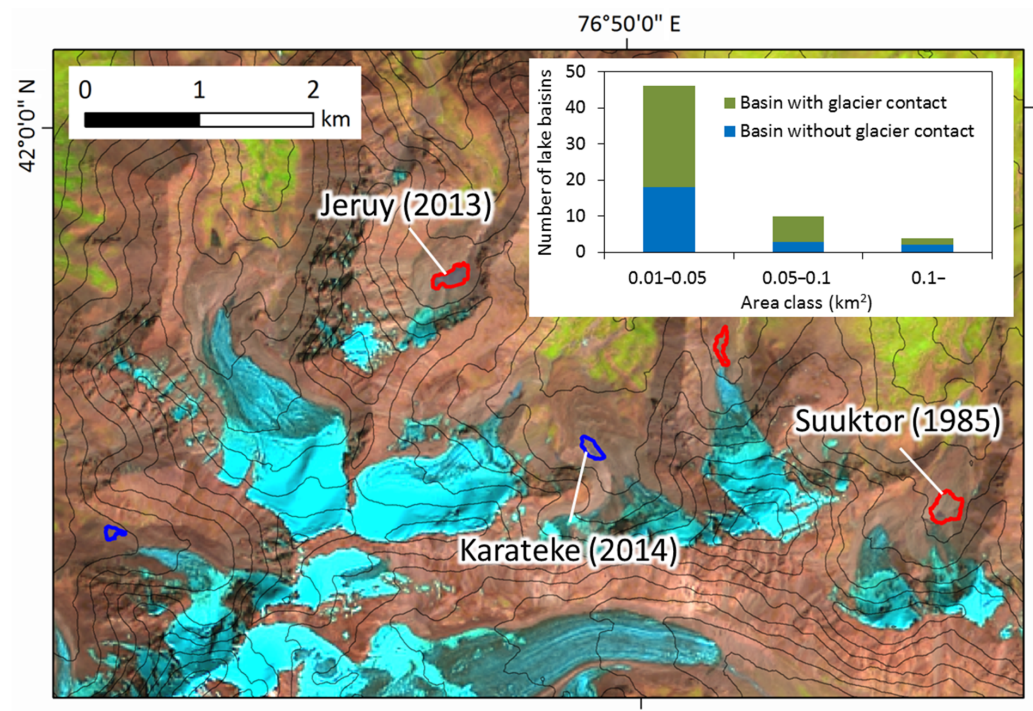

Figure 8. Depressions at glacier fronts in the study area (locations in Fig. 1). Red lines outline depressions with glacier contact and blue lines outline depressions without glacier contact. The inset shows size, number, and type (with glacier contact or without glacier contact) of depressions in the study area.

lake in front of them (Richardson et al., 2009; Komori et al., 2012; Rounce et al., 2017). In north-western Nepal, a supraglacial lake that developed temporally at a depression on a small alpine glacier caused a large drainage through an englacial conduit (Kropáček et al., 2015).

This drainage process differs from that typical of glacial lake outburst floods (GLOFs) in the eastern Himalayas. The Himalayan GLOF type occurs from a large proglacial lake that has expanded for several decades but then has its moraine dam fail (Yamada and Sharma, 1993; Ageta et al., 2000). Such a lake typically does not refill to the same depth as it had before failure. However, the lake area might expand again backwards due to glacier recession, or the water level might increase due to blockage of an outlet channel when a large-scale failure occurs at the moraine's inner slope (Ageta et al., 2000) or the dam opening is blocked by snow and ice 


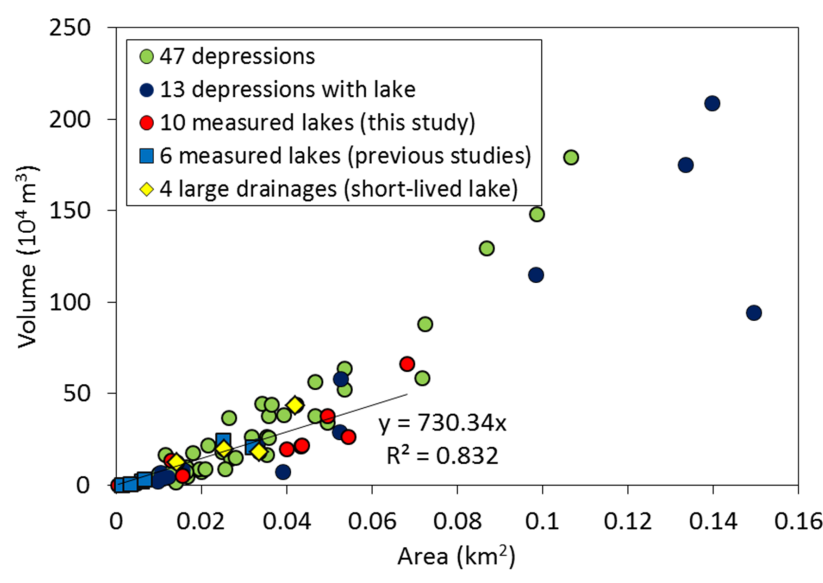

Figure 9. Volume and area of directly measured lakes and depressions. Thirteen depressions have an existing glacial lake. Five depressions have a lake area of more than $30 \%$ of the maximum filling area possible. (Data from six previously studied lakes, this study, and Igor Severskiy, personal communication, 2009; Janský et al., 2010)

(Huggel et al. 2003). After drainage, the failure is visible as a $\mathrm{V}$-shaped channel excavated across the moraine dam (Breien et al., 2008; Komori et al., 2012).

In contrast, the short-lived glacial lake type studied here appears and expands for a few months, and then discharges through ice tunnels. The lake appears in a depression that develops after recent glacier recession (Narama et al., 2010a). After drainage, vertical subsidence occurs along the subsurface channel in the debris landform. Such short-lived glacial lake types recur when their ice tunnel closes, similar to that on a supraglacial lake on a glacier or on a debris-covered glacier (Kropáček, et al., 2015; Benn et al., 2017; Narama et al., 2017). For example, at Angisay Glacier in the Teskey Range (Fig. 1), several floods occurred from the same glacial lake in 1974, 1975, and 1980 (Kubrushko and Staviskiy, 1978; Kubrushko and Shatravin, 1982). The repeated floods indicate that the lake water refills at the same lake basin due to a repeated closure of the ice-tunnel. Although existence of the lake could not be confirmed, the Ak-Say Glacier of the Kyrgyz Range also had repeated drainages in the 1980s (Janský et al., 2010; Zaginaev et al., 2016).

\subsection{Identifying potential lake basins of short-lived glacial lakes}

In addition to monitoring existing lakes, our findings suggest that one should also monitor empty depressions in which a short-lived glacial lake may form and later release a dangerous flood. But which depressions should be monitored? One can rule out some depressions by examining several features of the depression and its environment as follows, we suggest three criteria in the study area.
Our first criterion for selection for monitoring concerns size. For example, the Karateke lake drainage had a volume of $123000 \mathrm{~m}^{3}$, the smallest of the four large drainages we studied, and the lake had an area of $0.016 \mathrm{~km}^{2}$. As a result, we recommend monitoring depressions with areas exceeding $0.01 \mathrm{~km}^{2}$ on debris landforms with ice, also taking into account moderate future expansion from recent glacier recession. In this study, we selected depressions from those available that satisfied this criterion.

The second criterion is that the depression should have a clear source of meltwater. That is, a short-lived glacial lake cannot appear at a depression in which meltwater cannot inflow in substantial amounts. Among the 60 depressions $\left(>0.01 \mathrm{~km}^{2}\right)$ we examined in the northern part of the western Teskey Range, 37 of them had glacier contact and thus could get meltwater directly from glacier termini. The remaining 23 depressions had no glacier contact, but could also accumulate water, such as the Karateke lake (Fig. 3c). Thus, all 60 in our study also satisfy this criterion.

The third criterion is that the depression should not have a surface outflow channel. With such a channel, a short-lived lake cannot store much water in the short term. Using this consideration, we can exclude seven depressions that have surface outflow channels. As a result, 53 depressions among the 60 depressions are potential basins for a tunnel-type, short-lived glacial lake. Thus, these 53 would be important to monitor.

Other factors to consider are the timing of the ice-tunnel opening and the melting rate of ice and snow, both of which affect the water filling the depressions. In the study area, the lake water of the western Zyndan glacial lake overflowed before a large drainage on 24 July 2008. The overflow was due to a high snow and ice melting rate and the late timing of the ice-tunnel opening (Narama et al., 2010a). In contrast, an early timing of ice-tunnel opening or a small upstream melt rate might cause only a partial discharge.

In addition, the size (height and width) and distance of the ice tunnels and distance to the closure point determine the total stored water volume (lake plus conduits) because the closure point may be far downstream from the lake in the ice tunnel. Thus, the drainage volume depends on (i) the volume of the depression, (ii) the timing of the ice-tunnel opening, (iii) the melt rate of ice and snow, (iv) the size of the ice tunnel, and (v) the closure point of the ice tunnel.

\subsection{Transition to debris flow}

For lakes of the tunnel type, the flood wave without moraine deposits can transform into a debris flow where the channel gets steeper and the wall-material erodible. The change occurs because banks of the channels are often composed of loose material (Haeberli, 1983; Clague and Evans, 1994; Breien et al., 2008; Evans and Delaney, 2015). The mobility of the debris flow also depends on the type of loose erodible material. In the Ili Range of the northern Tien Shan, 
some cases of drainage started with a small initial failure volume that then increased by entrainment of material from the path, acquiring much debris from the middle of a steep mountain slope, resulting in very large deposits that exceeded $10^{6} \mathrm{~m}^{3}$ (Baimoldaev and Vinohodov, 2007; Evans and Delaney, 2015).

Two main types of debris flows occur, viscous and stony (Takahashi, 2004, 2009). For example, the Jeruy and Karateke lakes have about the same elevation (3815 and $3757 \mathrm{~m}$ a.s.l.) with only slightly different maximum discharge $\left(Q_{\max }\right)$ values of 14.9 and $11.5 \mathrm{~m}^{3} \mathrm{~s}^{-1}$. However, Jeruy's debris-flow type was a viscous flow with matrixsupported deposits (Fig. 6a), whereas Karateke's was a stony debris-flow with clast-supported deposits (Fig. 6b). To help us understand these differences, we also investigated the debris flows that occurred on 3 June 2009 from the Takyltor Glacier in the Kyrgyz Range.

Where does the channel erosion occur? We assume erosion occurs where net deposition does not occur. According to Hungr et al. (1984), net deposition in a channel starts where the channel angle is between 10 and $14^{\circ}$. Thus, we use the total distance over which the channel exceeds $10^{\circ}$ as defining the "erodible channel distance". This erodible channel distance agrees well with the actually eroded distance in the western Zyndan lake case (Narama et al., 2010a). Although the lake elevation, maximum discharge, and slope angles of the eroded section are about the same at the Jeruy and Karateke Valleys, the erodible channel distances vary significantly by valley (Fig. 6c, d).

Observations show that entrainment makes debris flows more and more erosive, resulting in a feedback effect (Breien et al., 2008). This effect partly explains the high rate of volume increase observed in many debris flows and is probably often necessary to achieve long runouts in subaerial flows.

We characterize potential flows by the erodible channel distance and the estimated maximum discharge. We estimate here the maximum discharge of 53 depressions and existing lakes using the duration of discharge and $Q_{\max }=46\left(V / 10^{6}\right)^{0.66}$ (tunnel event; Walder and Costa, 1996), with a water volume $V$. This formula neglects the possible role of tunnel size in total drainage volume. For an existing lake, $V$ is estimated using the regression formula in Fig. 9. In the study area, the erodible channel distances range between 166 and $6016 \mathrm{~m}$, and the maximum slope gradients of the mean erodible channel distance are $11.5-20.9^{\circ}$. We also characterize actual drainage events (the above four recent floods) using these two parameters.

The results, plotted in Fig. 10, suggest a classification in which each drainage is either a debris flow or water flood. Many short-lived lakes change from water flood to debris flows, involving debris entrainment (stony flow or viscous flow), due to the channel wall having looser material (including composition of material; fragmented rock or surficial materials; Evans and Delaney, 2015). With a transition boundary at an erodible channel distance of about $1500 \mathrm{~m}$, the western

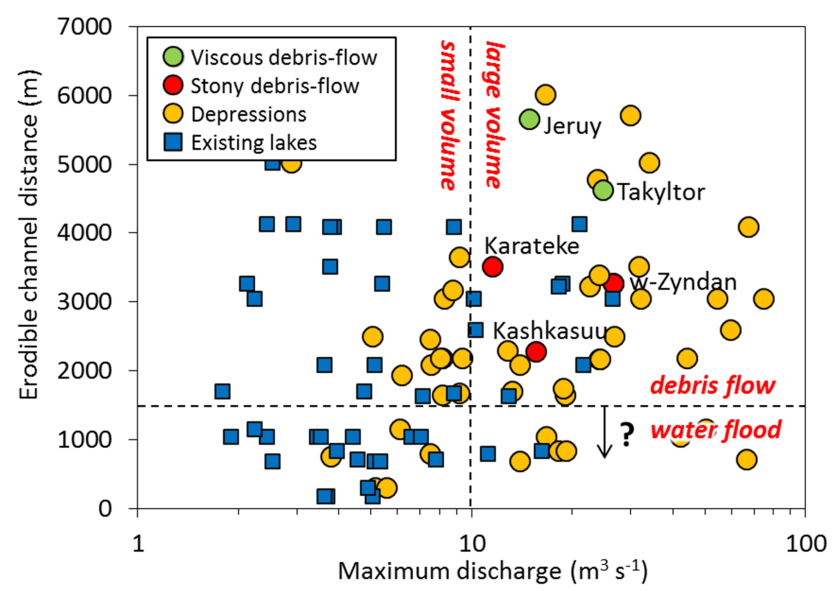

Figure 10. Drainage classification for the study area. The horizontal dashed line separates debris flows from water floods (which have little debris). The vertical dashed line separates high-volume from low-volume flows.

Zyndan, Karateke, Jeruy, Kashkasuu, and Takyltor floods are classified as debris flows in Fig. 10, and they have $Q_{\max }$ values of $11.5-26.6 \mathrm{~m}^{3} \mathrm{~s}^{-1}$. Among the 53 depressions, $34 \mathrm{de}-$ pressions exceed $10 \mathrm{~m}^{3} \mathrm{~s}^{-1}$ in possible maximum discharge (Fig. 10). However, for the existing lakes, many have a $Q_{\max }$ below $10 \mathrm{~m}^{3} \mathrm{~s}^{-1}$.

Thus, the drainage of short-lived lakes in the study region shows a transition between water flood and debris flow. The debris entrainment along the erodible channel distance can add a considerable amount of debris deposits. Depending on the situation, the debris flow may be stony or viscous flow. Although the influence of most debris flows from the shortlived lakes is limited to the valley mouth or river sides on the mountain piedmont, the deposition region may in some cases have a long runout if the fluidity increases with distance along the flow.

\subsection{Differences in flood damage}

On the alluvial fan downstream of the Jeruy Valley, two debris-flow streams separated from the present river channel and caused large damages to agriculture fields, irrigation infrastructure, roads, and many tombs. In comparison, in the Karateke Valley only two bridges were broken, as the outburst stream was limited along the river. In Shahimardan village, where a flood killed more than 100 residents (UNEP, 2007), many lived along the river. In the Dasht village, where a flood killed 25 people (Mergili et al., 2012), the debris flow covered the village on the alluvial fan.

The degree of flood damage is related to the local landuse and the landform type (e.g., alluvial fan) at the valley mouth. During the western Zyndan lake drainage in 2008, the flood damaged a kashaal (animal cottage) on the alluvial fan (Narama et al., 2010a). Among the 23 valleys included in the study area in the northern part of the west- 
ern Teskey Range(Fig. 1), 14 valleys are a valley landform (e.g., Karateke case), the other 9 being an alluvial fan type (e.g., Jeruy case). The drainages from the four short-lived lakes studied here are less than $500000 \mathrm{~m}^{3}$ and their flood damages are limited along the river or alluvial fan. As many depressions are up to $500000 \mathrm{~m}^{3}$ in this region, most flood damages are considered to be likely limited along the river or alluvial fan at the valley mouth. Although some large depressions have existed here, we know of no case in which a large lake had a large drainage. However, for risk mitigation, drainages from short-lived lakes should become an integral part of river basin management in the region, considering depression volume, flood type, land-use, and landforms potentially affected.

\section{Conclusions}

In the western Teskey Range, recent large lake drainages have come from the tunnel-type of short-lived glacial lakes, which appear and then drain within a few months. These lakes were found to typically appear as small ponds in May, then expand in June and July due to rapid melting of ice and snow in the upstream area. The lake damming appears due to the blockage and closure of ice tunnels, as a result of winter freezing of stored water, or deposition of ice and debris by tunnel collapses. The drainage then occurs between the end of July and mid-August when the ice tunnel re-opens, due to ice melting or the blocked section flushed away. Using the estimated drainage volumes from the current lakes or depressions, we argue that their flood damages will occur only at their alluvial fans or along the river at their mountain piedmont. Most of the drainage events led to debris flows.

The geomorphological characteristics under which these lakes appear were found to be (i) a debris landform including dead ice (ice-cored moraine complex) with the potential to form an ice tunnel, (ii) a depression $\left(>0.01 \mathrm{~km}^{2}\right)$ on the debris landform with sufficient water supply, and (iii) no visible outflow channel from the depression, thus requiring the water to exit through an ice tunnel.

The comparably short period of a few months between appearance and drainage of the short-lived lake type studied here poses a special challenge to the application of satellite remote sensing for monitoring them. However, new satellite constellations such as Sentinel-2 (5 days repeat; Kääb et al., 2016) or the Planet cubesat constellation (daily repeat, Kääb et al., 2017) will help to detect even short-term changes. The applicability of Sentinel-1 radar data (6 days repeat) for monitoring these lakes remains to be tested (Strozzi et al., 2012). For such systematic surveillance, the type of prioritization of potentially dangerous sites as those proposed here is essential. We propose an early information network based on monitoring with satellite data that informs the responsible authorities, and possibly local people, when a lake appears. As glacier-lake workshops in the Ladakh region of India (Ikeda et al., 2016) and in Jeruy village (study area) showed, improvement of knowledge and land-use can help reduce the impact of large drainage floods form glacial lakes.

In the Tien Shan, depressions $\left(>0.01 \mathrm{~km}^{2}\right)$ in which water can inflow should be monitored, just as we now monitor glacial lakes, and their potential associated hazards considered. Lake monitoring using satellite data should proceed based on the criteria of potential dangerous lakes outlined here such as the location and volume of the lakes and depressions, the flood type, and landform on the mountain pediment.

Data availability. Some data produced for use in this study can be provided upon request.

Competing interests. The authors declare that they have no conflict of interest.

Acknowledgements. Special thanks are owed to Bolot Moldobekov, Sheishenaly Usupaev, Cholponbek Ormukov of the Central-Asian Institute for Applied Geosciences (CAIAG), Anarkul Aitaliev of the Ministry of Emergency Situations of the Kyrgyz Republic, Igor Severskiy of the Institute of Geography, Kazakhstan, Sergey Erokhin of the Geological Institute of the Kyrgyz Republic, Minako Yamamoto, Yoshitaka Mori and Hideyuki Takadama of Niigata University, and the local residents of the study area. We also thank our editor Filippo Catani, Adam Emmer and two anonymous reviewers for valuable comments. This study was supported by the Mitsui \& Co. Environmental Fund in 2013-2015 and Grant-in-Aid for Scientific Research (C) 25350422 and (B) $16 \mathrm{H} 05642$ of the Ministry of Education, Culture, Sports, Science and Technology (MEXT), and Heiwa Nakajima Research Foundation. This study used ALOS satellite image data from ALOS Research Announcement (RA) in the framework of JAXA EORC. Andreas Kääb acknowledges support by the European Research Council under the European Union's Seventh Framework Programme (FP/2007-2013)/ERC grant agreement no.320816, and the European Space Agency (ESA) within the Glacier_CCI (code 400010177810IAM) and DUE GlobPermafrost projects (4000116196/15/IN-B). This work is also a contribution to the SIU CryoJaNo project (HNP-2015/10010).

Edited by: Filippo Catani

Reviewed by: Adam Emmer and two anonymous referees

\section{References}

Abdrakhmatov, K., Weldon, R., Thompson, S., Burbank, D., Rubin, C., Miller, M., and Molnar, P.: Onset, style and current rate of shortening in the central Tien Shan, Kyrgyz Republic, Russ. Geol. Geophys., 42, 1585-1609, 2001.

Ageta, Y., Iwata, S., Yabuki, H., Naito, N., Sakai, A., Narama, C., and Karma: Expansion of glacier lakes in recent decades in the Bhutan Himalayas, in: Debris-Covered Glaciers, Proceedings of 
a workshop held at Seattle, edited by: Nakawo, M., Raymond, C.F., and Fountain, A., IAHS Publication, Washington, USA, 264, 165-175, 2000.

Aizen, V. B., Aizen, E. M., and Melack, J. M.: Climate, snow cover, glaciers, and runoff in the Tien Shan, Central Asia, J. Am. Water. Resour. As., 31, 1113-1129, 1995.

Baimoldaev, T. and Vinohodov, B.: Kazselezaschita, Ministry of Education and Science, Almaty, 283 pp., 2007 (in Russian).

Benn, D. I., Wiseman, S., and Hands, K. A.: Growth and drainage of supraglacial lakes on debris-mantled Ngozumpa Glacier, Khumbu Himal, Nepal, J. Glaciol., 47, 626-638, 2001.

Benn, D. I., Thompson, S., Gulley, J., Mertes, J., Luckman, A., and Nicholson, L.: Structure and evolution of the drainage system of a Himalayan debris-covered glacier, and its relationship with patterns of mass loss, The Cryosphere, 11, 2247-2264, https://doi.org/10.5194/tc-11-2247-2017, 2017.

Bolch, T. and Gorbunov, A. P.: Characteristics and origin of rock glaciers in northern Tien Shan (Kazakhstan/ Kyrgyzstan), Permafrost Periglac., 25, 320-332, 2014.

Breien, H., De Blasio, F. V., Elverhøi, A., and Høeg, K.: Erosion and morphology of a debris flow caused by a glacial lake outburst flood, Western Norway, Landslides, 5, 271-280, 2008.

Burgette, R. J., Weldon, R. J., Abdrakhmatov, K. Y., Ormukov, C., Owen, L. A., and Thompson, S. C.: Timing and process of river and lake terrace formation in the Kyrgyz Tien Shan, Quaternary Sci. Rev., 159, 15-34, 2017.

Clague, J. J. and Evans, S. G.: A review of catastrophic drainage of moraine-dammed lakes in British Columbia, Quaternary Sci. Rev., 19, 1763-1783, 1994.

Emmer, A., Loarte, E., Klimeš, J., and Vilímek, V.: Recent evolution and degradation of the bent Jatunraju glacier (Cordillera Blanca, Peru), Geomorphology, 228, 345-355, 2015.

Evans, S. G. and Delaney, K. B.: Catastrophic mass flows in the mountain glacial environment, in: Snow and Ice-Related Hazards, Risks, and Disasters, edited by: Haeberli, W., Whiteman, C., and Shroder, J. F., Elsevier, Amsterdam, 563-606, 2015.

Gulley, J. and Benn, D.I.: Structure control of englacial drainage systems in Himalayan debris-covered glaciers, J. Glaciol., 53, 339-412, 2007.

Gulley, J. D., Benn, D. I., Müller, D., and Luckman, A.: A cut-andclosure origin for englacial conduits in uncrevassed regions of polythermal glaciers, J. Glaciol., 55, 66-80, 2009.

Haeberli, W.: Frequency and characteristics of glacier floods in the Swiss Alps, Ann. Glaciol., 4, 85-90, 1983.

Haeberli, W., Kääb, A., Paul, F., Chiarle, M., Mortara, G., Mazza, A., Deline, P., and Richardson, S.: A surge-type movement at Ghiacciaio del Belvedere and a developing slope instability in the east face of Monte Rosa, Macugnaga, Italian Alps, Norsk Geogr. Tidsskr., 56, 104-111, 2002.

Harrison, W. D., Osipova, G. B., Nosenko, G. A., Espizua, L., Kääb, A., Fischer, L., Huggel, C., Craw Burns, P. A., Truffer, M., and Lai, A. W.: Glacier Surges, in: Snow and Ice-Related Hazards, Risks, and Disasters, edited by: Haeberli, W., Whiteman, C., and Shroder, J. F., Elsevier, Amsterdam, 437-485, 2015.

Huggel, C., Kääb, A., Haeberli, W., and Krummenacher, B.: Regional-scale GIS-models for assessment of hazards from glacier lake outbursts: evaluation and application in the Swiss Alps, Nat. Hazards Earth Syst. Sci., 3, 647-662, https://doi.org/10.5194/nhess-3-647-2003, 2003.
Hungr, O., Morgan, G. C., and Kellerhals, R.: Quantitative analysis of debris torrent hazards for design of remedial measures, Can. Geotech. J., 21, 663-677, 1984.

Ikeda, N., Narama, C., and Gyalson, S.: Knowledge sharing for disaster risk reduction: Insights from a glacier lake workshop in the Ladakh region, Indian Himalayas, Mt. Res. Dev., 36, 31-40, 2016.

Janský, B., Šobr, M., and Engel, Z.: Outburst flood hazard: Case studies from the Tien-Shan Mountains, Kyrgyzstan, Limnologica, 40, 358-364, 2010.

Kääb, A., Winsvold, S. H., Altena, B., Nuth, C., Nagler, T., and Wuite, J.: Glacier remote sensing using Sentinel-2. Part I: Radiometric and geometric performance, and application to ice velocity, Remote Sensing, 8, 598, https://doi.org/10.3390/rs8070598, 2016.

Kääb, A., Altena, B., and Mascaro, J.: Coseismic displacements of the 14 November $2016 M_{w} 7.8$ Kaikoura, New Zealand, earthquake using the Planet optical cubesat constellation, Nat. Hazards Earth Syst. Sci., 17, 627-639, https://doi.org/10.5194/nhess17-627-2017, 2017.

Katuzov, S. and Shahgedanova, M.: Glacier retreat and climatic variability in the eastern Teskey-Alatoo, inner Tien Shan between the middle of the 19th century and beginning of the 21 st century, Global Planet. Change, 69, 59-70, 2009.

Komori, J., Gurung, D. R., Iwata, S., and Yabuki, H.: Variation and lake expansion of Chubda Glacier, Bhutan Himalayas, during the last 35 years, Bulletin of Glaciological Research, 21, 49-56, 2004.

Komori, J., Koike, T., Yamanokuchi, T., and Tshering, P.: Glacial lake outburst events in the Bhutan Himalayas, Global Environmental Research, 16, 59-70, 2012.

Kropáček, J., Neckel, N., Tyrna, B., Holzer, N., Hovden, A., Gourmelen, N., Schneider, C., Buchroithner, M., and Hochschild, V.: Repeated glacial lake outburst flood threatening the oldest Buddhist monastery in north-western Nepal, Nat. Hazards Earth Syst. Sci., 15, 2425-2437, https://doi.org/10.5194/nhess-15-2425-2015, 2015.

Kubrushko, S. S. and Staviskiy, Y. S.: Glacier lakes of Kyrgyz and their role in mudflow formation, Data of glaciological studies, 32, 59-62, 1978 (in Russian).

Kubrushko, S. S. and Shatravin, V. I.: Long-term prediction of glacial mudflows in Tien Shan, Data of Glaciological Studies, 43, 60-62, 1982 (in Russian).

Mergili, M., Kopf, C., Müllebner, B., and Schneider, J. F.: Changes of the cryosphere and related geohazards in the high-mountain areas of Tajikistan and Austria: A comparison, Geografiska Annaler: Series A, Physical Geography, 94, 79-96, 2012.

Mergili, M., Müller, J. P., and Schneider, J. F.: Spatio-temporal development of high-mountain lakes in the headwaters of the Amu Darya River (Central Asia), Global Planet. Change, 107, 13-24, 2013.

Miles, E. S., Willis, I. C., Arnold, N. S., and Steiner, J.: Spatial, seasonal and interannual variability of supraglacial ponds in the Langtang Valley of Nepal, 1999-2013, J. Glaciol., 63, 88-105, 2017a.

Miles, E. S., Steiner, J. F., Willis, I., Buri, P., Immerzeel, W. W., Chesnokova, A., Pellicciotti, F.: Pond dynamics and supraglacial-englacial connectivity on debris- 
covered Lirung Glacier, Nepal, Front. Earth Sci., 5, 1-19, https://doi.org/10.3389/feart.2017.00069, 2017b.

Nagai, H., Ukita, J., Narama, C., Fujita, K., Sakai, A., Tadono, T., Yamanokuchi, T., and Tomiyama, N.: Evaluating the scale and potential of GLOF in the Bhutan Himalayas using a satellitebased integral glacier-glacial lake inventory, Geosciences, 7, 77, https://doi.org/10.3390/geosciences7030077, 2017.

Narama, C., Shimamura, Y., Nakayama, D., and Abdrakhmatov, K.: Recent changes of glacier coverage in the western TerskeyAlatoo range, Kyrgyz Republic, using Corona and Landsat, Ann. Glaciol., 43, 223-229, 2006.

Narama, C., Severskiy, I., and Yegorov, A.: Current state of glacier changes, glacial lakes, and outburst floods in the Ile Ala-Tau and Kungöy Ala-Too ranges, northern Tien Shan Mountains, Geographical Studies, 84, 22-32, 2009.

Narama, C., Duishonakunov, M., Kääb, A., Daiyrov, M., and Abdrakhmatov, K.: The 24 July 2008 outburst flood at the western Zyndan glacier lake and recent regional changes in glacier lakes of the Teskey Ala-Too range, Tien Shan, Kyrgyzstan, Nat. Hazards Earth Syst. Sci., 10, 647-659, https://doi.org/10.5194/nhess10-647-2010, 2010a.

Narama, C., Kääb, A., Duishonakunov, M., and Abdrakhmatov, K.: Spatial variability of recent glacier area changes in the Tien Shan Mountains, Central Asia, using Corona ( 1970), Landsat $(\sim 2000)$, and ALOS $(\sim 2007)$ satellite data, Global Planet. Change, 71, 42-54, $2010 \mathrm{~b}$.

Narama, C., Daiyrov, M., Kazehare, S., Yamamoto, M., and Tadono, T.: Glacier lake inventory of the northern Tien Shan - Kyrgyz, Kungoy, and Teskey Ala-Too Ranges - Report of Mountain Research Group of Niigata University, Niigata, Japan, Niigata Printing, 2015.

Narama, C., Daiyrov, M., Tadono, T., Yamamoto, M., Kääb, A., Morita, R., and Ukita, J.: Seasonal drainage of supraglacial lakes on debris-covered glaciers in the Tien Shan Mountains, Central Asia, Geomorphology, 286, 133-142, 2017.

Richardson, S. D., Quincey, D. J., and Focus Humanitarian Assistance: The 2008 outburst floods from Ghulkin Glacier, Karakoram, Pakistan, Glacier hazards workshop, Universität für Bodenkultur, BOKU, Vienna, 2009.
Rounce, D. R., Byers, A. C., Byers, E. A., and McKinney, D. C.: Brief communication: Observations of a glacier outburst flood from Lhotse Glacier, Everest area, Nepal, The Cryosphere, 11, 443-449, https://doi.org/10.5194/tc-11-443-2017, 2017.

Shatravin, V. I.: Reconstruction of glaciation in the Pleistocene and Holocene based on new method, in: Climate, Glaciers, Lakes of Tien-Shan: travel in the past, edited by: Romanovsky, V. V., The Institute of Water Problems and Hydropower, Bishkek, 26-46, 2007 (in Russian).

Strozzi, T., Wiesmann, A., Kääb, A., Joshi, S., and Mool, P.: Glacial lake mapping with very high resolution satellite SAR data, Nat. Hazards Earth Syst. Sci., 12, 2487-2498, https://doi.org/10.5194/nhess-12-2487-2012, 2012.

Tadono, T., Kawamoto, S., Narama, C., Yamanokuchi, T., Ukita, J., Tomiyama, N., and Yabuki, H.: Development and validation of new glacial lake inventory in the Bhutan Himalayas using ALOS "DAICHI", Global Environ. Res., 16, 31-40, 2012.

Takaku, J. and Tadono, T.: PRISM on-orbit geometric calibration and DSM performance, IEEE T. Geosci. Remote Sens., 47, 4060-4073, 2009.

Takahashi, T.: Mechanism and countermeasure of debris flow, Kinmirai-sha, Nagoya, 432 pp., 2004 (in Japanese).

Takahashi, T.: A review of Japanese debris flow research, International Journal of Erosion Control Engineering, 2, 1-14, 2009.

UNEP (United Nations Environment Programme): Global Outlook for Ice and Snow, UNEP, Nairobi, 235 pp., 2007.

Walder, J. S. and Costa, J. E.: Outburst floods from glacier-dammed lakes: The effect of mode of lake drainage on flood magnitude, Earth Surf. Proc. Land., 21, 701-723, 1996.

Watanabe, T. and Rothacher, D.: The 1994 Lugge Tsho glacial lake outburst flood, Bhutan Himalaya, Mt. Res. Dev., 16, 77-81, 1996.

Yamada, T. and Sharma, C. K.: Glacier lakes and outburst floods in the Nepal Himalaya, IHAS Publication, 218, 319-330, 1993.

Zaginaev, V., Ballesteros-Cánovas, J. A., Erokhin, S., Matov, E., Petrakov, D., and Stoffel, M.: Reconstruction of glacial lake outburst floods in northern Tien Shan: Implications for hazard assessment, Geomorphology, 269, 75-84, 2016. 